\title{
Functional analysis of trellising systems and their impact on quality and productivity in passion fruit (Passiflora edulis Sims $f$. Flavicarpa and $f$. Pupurea, Degener) cultivars in Colombia
}

\author{
José-Alejandro Cleves-Leguízamo ${ }^{1}$
}

\begin{abstract}
In the last decade, passion fruit cultivation has regained special importance expressed in the increase of the planting area in order to supply growing markets. This study systematizes research and production experiences gathered in more than three decades of technical work in the central region of Colombia, at locations of Valle del Cauca, Cauca, Huila, Tólima, Quindio and Risaralda. Extensive field visits were conducted with farmers, students and technicians. Initially, general information on passion fruit cultivation, edaphoclimatic requirements are reviewed, analyzing the effect of climatological variables such as wind speed, relative humidity, temperature, rainfall and sunshine, in intensive production processes, which are manifested in the monthly distribution of production volume, expressed as percentage, taking as a reference the three support and conduction systems (simple trellis, "T" system and double cordon), highlighting attributes, advantages, disadvantages and their relationship with productivity and quality. Finally, the effect of pollinating agents was described. It was concluded that according to the ecophysiological requirements of passion fruit cultivation under tropical Colombian conditions, the trellising system, which presents the greatest advantages for cultural and phytosanitary management is the simple trellis, obtaining higher production volumes of optimum quality.

Index terms: Tropical fruit production; production systems; productivity; passion flowers; yellow passion fruit; purple passion fruit.
\end{abstract}

\section{Análise funcional de sistemas de condução e seu impacto na qualidade e produtividade de cultivares de maracujá (Passiflora edulis Sims f. Flavicarpa e $f$. Pupurea, Degener) na Colômbia}

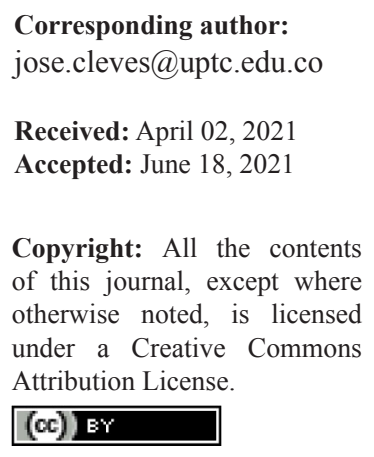

Corresponding author: jose.cleves@uptc.edu.co

Received: April 02, 2021 Accepted: June 18, 2021

Copyright: All the contents of this journal, except where under a Creative Commons Attribution License.

(c) EY
Resumo-Na última década, o cultivo do maracujá voltou a ganhar especial importância, expressa no aumento da área de plantio, para abastecer mercados em crescimento. Este estudo sistematiza as experiências de pesquisa e de produção acumuladas em mais de três décadas de trabalho técnico na região central da Colômbia, nas localidades de Valle del Cauca, Cauca, Huila, Tólima, Quindio e Risaralda. Visitas de campo foram realizadas com agricultores, estudantes e técnicos. Inicialmente, informações gerais sobre o cultivo do maracujá e requisitos edafoclimáticos são avaliadas, analisando a incidência de variáveis climatológicas, como velocidade do vento, umidade relativa, temperatura, precipitação e insolação, em processos intensivos de produção, que se manifestam na distribuição mensal do volume de produção, expresso em percentagem, tendo como referência os três sistemas de condução (espaldadeira, latada e cordão), destacando os atributos, as vantagens, as desvantagens e sua relação com a produtividade e a qualidade. Finalmente, o efeito de agentes polinizadores será descrito. Concluiu-se que, de acordo com as exigências ecofisiológicas do cultivo do maracujá em condições tropicais colombianas, o sistema de treliça que apresenta maiores vantagens para o manejo cultural e fitossanitário, é a treliça simples, obtendo maiores volumes de produção de ótima qualidade.

Termos para indexação: Produção de frutas tropicais; sistemas de produção; produtividade; flores da paixão; maracujá-amarelo; maracujá-roxo.

\footnotetext{
${ }^{1}$ Agronomist Engineer; MsC in Phytotechnics; PhD in Agroecology, Full-Time, Research Professor, Universidad Pedagógica y Tecnológica de Colombia (U.P.T.C.), Facultad Seccional Duitama, Escuela de Administración de Empresas Agropecuarias (A.E.A.), Duitama, Colombia. E-mail: jose.cleves@uptc.edu.co(ORCID 0000-0001-9717-9753)
} 


\section{Introduction}

The edaphoclimatic conditions of the Colombian middle tropics present a series of competitive advantages for the establishment, development and production of fruits of great interest due to their nutritional and nutraceutical properties in specialized markets characterized by high competitiveness (CAMPOS et al., 2018). Adequate rainfall (volume and distribution), both in the Andean region and in the Orinoquia, allows permanent planting and therefore continuous supply at any time of the year (FISCHER et al., 2018).

The plant is a semi-perennial climbing liana with slightly angled herbaceous stem and axillary tendrils, over time it becomes semi-woody, with glossy leaves, alternate, trilobulate, leathery; axillary flowers, fragrant, showy, entomophilous, axillary, solitary, allogamous (cross-pollination). There are three types that differentiate by the style curvature (TC; PC; SC), provided with five petals, five stamens, three stigmas and crown with purple radiating filaments at the base and white at the apex; the fruit is a globose or ovoid berry with intense red to yellow color; seeds have very aromatic fleshy aryl; fasciculate, superficial, plagiotropic root, $70 \%$ of the volume is located in the first $30 \mathrm{~cm}$; indeterminate growth, with overlap between vegetative and reproductive growth (AVILÁN et al., 1992; PRIMOT et al., 2005; CLEVES et al., 2012).

The most generalized form of propagation is by seed (sexual) due to the ease of seedling formation; therefore, the quality of seeds is a fundamental factor for the yield and quality of the final product (SILVA et al., 2020).

The name of the family means "flower of passion" (passion fruit), which is due to the relationship that the Spanish conquerors had between the flower and ornaments used in the crucifixion of Jesus Christ (ARISTIGUIETA, 1950).

Passion fruit is a plant of tropical origin, specifically from the Amazon region of Brazil, Peru and Colombia (BLANCKE, 2016). This condition places our country in a privileged position as a producer and exporter of one of the best juices and concentrates in the world. The fruit is a source of proteins, minerals, vitamins, carbohydrates. The average passion fruit composition is as follows: peel (source of pectin) 50-60\%; juice 30-40\% and seed (source of fat) $10-15 \%$ (FNC,1987).

Colombia and Brazil have the greatest diversity of wild and commercial Passiflora variety (NUNES DE JESÚS; FALEIRO, 2017; OCAMPO et al., 2020; FISCHER, 2000) and are considered as centers of distribution and biodiversity (RODRÍGUEZ et al., 2020).
Most of the species are edible fruits, with vast geographic distribution in North America, South America, the Caribbean region, the Galapagos Islands, Africa, Asia, Oceania, the Philippines and Australia. Our continent is the center of diversity of the genus Passiflora, which comprises $95 \%$ of all species (NAKASOME; PAUL, 1998).

Passion fruit belongs to the Passifloraceae family, with more than 600 species grouped into 18 genera. The highest number of species has been reported in Colombia: 167 (ESCOBAR, 1991), grouped into three genera Ancistrothyrsus (2), Dilkea (4) and Passiflora (161), of which 123 are located in the Andean region, with 57 endemic species (OCAMPO et al., 2007; OCAMPO; WYCKHUYS, 2012), and nine species are commercially cultivated (LIGARRETO, 2012).

Passion fruit cultivated for three decades occupies a very prominent place in tropical fruit growing, and is considered a technically and economically viable option, due to its rapid and high economic return (MELETTI, 2011; MELETTI et al., 2010).

The most economically important species cultivated in Colombia is passion fruit (Passiflora edulis Sims f. Flavicarpa Degener) (DELGADO et al., 2013). The potential yield and quality of the fruit is linked to the propagation system used, the vigor of the genetic matrix, environmental management and supply practices (MARTÍNEZ et al., 2009). The taxonomic classification is shown in Table 1.

Table 1. Taxonomic classification of passion fruit (Passiflora edulis Sims F. Flavicarpa and f. Pupurea Degener).

\begin{tabular}{l|l} 
Division: & Spermatophyte \\
Subdivision: & Angiosperm \\
Class: & Dicotyledonous \\
Subclass: & Archiclamids \\
Order: & Perietals \\
Suborder: & Flacourtia \\
Family: & Plassifloraceae \\
Genus: & Passiflora \\
\hline Species: & Edulis \\
\multicolumn{1}{c|}{ Source: Amaya, (2009). } &
\end{tabular}

Passion fruit is used for fresh consumption or as a raw material in industrial processes (TIGRERO et al., 2016); this fruit is very important for its taste, pharmacodynamic (use in herbal medicine) or functional (source of alkaloids such as pasiflorina and harmana, phenolic compounds, flavonoids), mainly its juice, peel and seeds (source of oils and carbohydrates), nutraceutical and also ornamental (REINA et al., 1997). 
The most economically important species are: curuba (Passiflora tripartita var mollissima Bailey), badea (Passiflora quadrangularis), granadilla (Passiflora ligularis Juss), gulupa (Passiflora edulis f. Edulis Sims) and cholupa (Passiflora maliformis L), and species of economic importance mainly in Brazil are: yellow passion fruit (Passiflora edulis Sims); sweet passion fruit (Passiflora alata Dryand); pearl passion fruit (Passiflora setacea DC); Caatinga passion fruit (Passiflora cincinnata Mast); passion fruit (Passiflora nítida Kunth) and blue passion fruit (Passiflora caerulea L. var. Regnellii); passion flower (Passiflora incarnata); garlic passion fruit (Passiflora tenuifila); two-flowered passion fruit (Passiflora biflora Lam). (FNC, 1987; DAMATTO et al., 2005; FALEIRO et al., 2019; PROIMPRESS-CEPASS, 2020).

Phenotypically, they differ by their external appearance (color, size, weight) into two colors; yellow passion fruit adapted to the conditions of the low and middle tropics (0-1000 meters above sea level) is a rustic plant with greater vigor compared to purple passion fruit, and under this condition, guarantees rapid return on invested capital (SILVA et al., 2020). Red or purple passion fruit is adapted to the conditions of the middle tropics (higher than 1300 meters above sea level) and fruits are smaller.
In Colombia, yellow passion fruit was introduced in the 1960s with seeds from Hawaii. For the year 2019, the sowing area was estimated at 23,701 hectares with production volume of 241,393 tons (MINISTRY OF AGRICULTURE, 2019), with $50 \%$ of production being concentrated in locations of Meta, Valle del Cauca and Huila (OCAMPO et al., 2017). The Purple form, by sequences of mutations, gave rise to the Flavicarpa form. In Colombia, three ecotypes are identified (Table 2).

Table 2. Main passion fruit ecotypes (Passiflora edulis Sims $f$. Flavicarpa and f. Pupúrea Degener) in Colombia.

\begin{tabular}{lccc}
\hline Color & Origen & Size & Fruit weight (gr) \\
\hline Yellow & Hawaii & Large & 100 \\
Yellow & Brazil-Venezuela & Small & 66 \\
Purple & Africa & Medium & 80 \\
\hline
\end{tabular}

Source: Cleves et al. (2012).

Passion fruit is a perfect, self-sterile hermaphroditic plant, and fertilization requires natural cross pollination (NCP), so that genomic segregation is high. Under these conditions, it is not possible to consider varieties as such, and the most appropriate is to consider ecotypes, that is, differentiated forms depending on the environmental offer, that is, on a specific habitat, on particular ecosystem (CLEVES, 2012). The ecophysiological requirements are indicated in Table 3.

Table 3. Ecophysiological requirements for passion fruit cultivation (Passiflora edulis Sims F. Flavicarpa and $f$. Pupurea Degener).

\begin{tabular}{l|l}
\hline \multicolumn{1}{c|}{ Requirement } & \multicolumn{1}{c}{ Description } \\
\hline Life zone & Tropical dry forest (TDF); Tropical humid forest (THF) \\
Temperature & $\geq 15^{\circ} \mathrm{C}$; range: $20-32{ }^{\circ} \mathrm{C}$; optimum $24-28^{\circ} \mathrm{C}$ \\
Relative humidity & $\geq 30 \%$; optimum $60-70 \%$ \\
Rainfall & $\leq 2000 \mathrm{~mm} /$ year, range: $800-1500 \mathrm{~mm} /$ year; optimum $800-1200 \mathrm{~mm} /$ year \\
Altitude & $0-1800$ (masl) optimum 900-1200 (masl) \\
Winds & $\leq 38 \mathrm{~km} / \mathrm{h}$; Moderate (cool breeze); optimum 13-21 Km/h \\
Cloudiness & Clear (low density) \\
Photoperiod & Long heliophany $\geq 5$ hours light/day \\
Soils & Deep \\
Texture & Light: Sandy (A); Loam-sandy (A-F); Sandy Clay Loam (F-A); Loam (F). \\
Structure & Columnar; Granular \\
Drainage & Superficial (passive) \\
Infiltration rate & Fast \\
pH & $4,5-7,0 ;$ optimum 6.5; moderately tolerant to alkaline soils \\
Base saturation (\%) & $\geq 60 \%$ \\
Organic matter & $\geq 4 \%$ \\
Slope & Moderate; lower than 30\%; optimum 3-25\% \\
\hline
\end{tabular}

Source: Own elaboration (2021), based on Didier (2001); Cleves et al. (2012); IDEAM (2018); Faleiro et al. (2020). 


\section{Materials and methods}

This study systematizes investigative and productive experiences collected in more than three decades of technical exercise in the central region of Colombia (locations of Valle del Cauca, Cauca, Huila, Tólima, Quindio, Risaralda), conducting field trips with farmers, students and technical assistants.

In total, sixty basic and applied research works were developed, the vast majority corresponding to undergraduate thesis at technical, technological and professional level. Collected data were organized in a database for later systematization, interpretation and analysis, with the understanding that farmers in their continuous productive processes have contributed to the expansion of the area of passion fruit cultivation in Colombia, proposing and developing new pathogen management and control practices based on accumulated community experience (OCAMPO et al., 2017; OCAMPO et al., 2017a).

Records of the following climatological variables were analyzed: rainfall, temperature, relative humidity and sunshine. Production data were collected from 30year historical records (1987-2017). In our country, the crop adapts well to different thermal floors and altitudes in a range between 0 and 1800 meters above sea level, optimum being 900-1200 meters above sea level, information was obtained precisely from productive units located at this altitude range.

\section{Results}

Below are the most significant results regarding the incidence of winds, relative humidity, rainfall, temperature (average), light (solar radiation), in the three support systems (simple trellis, "T" system and double cordon) related to the historical results collected in primary and secondary sources with growers located in the central region of the country, analyzing climatic and production records in an observation window of 30 and 20 years, respectively.

1.Effect of climatic factors on passion fruit production (Passiflora edulis Sims $f$. Flavicarpa and f. Pupurea Degener): Under the tropical conditions of the study area, the environmental offer directly affects quality, shelf life and nutrition of fruits (FISCHER et al., 2016) and analyzing the incidence of environmental effects on the physiological processes of the plant is of vital importance to optimize production techniques. The effect of the main climatological variables on passion fruit production, fruit quality, specifically the peel / juice and color ratio is described below (AULAR et al., 2002).
1.1 Winds: Due to the infrastructure required for the technical assembly of crops, passion fruit behaves like a "living barrier", which makes the crop vulnerable to the action of strong winds.

Wind speeds greater than $50 \mathrm{~km} / \mathrm{h}$ limit crop development, and wind incidence is expressed in:

- Light winds have beneficial effects on plant physiology and have a cooling effect when high temperatures are present.

- Wind has an effect that contributes to the drying of leaves and fruits after the occurrence of rains.

- Winds contribute to gas exchange $\left(\mathrm{CO}_{2}\right.$ renewal $)$

- Strong winds cause plant uprooting (establishment phase)

- Fall of the trellising system.

- Mechanical damage to vegetative and reproductive structures

- Limitation of the movement of pollinating fauna

- Reduction in post-harvest fruit size, weight and yield

- Loss of irrigation uniformity

- Decrease in the efficiency of foliar spraying of agrochemicals (FISCHER et al., 2009).

1.2 Relative humidity: It refers to the relationship expressed in percentage (\%) between the amount of real water vapor in the air and that required to saturate at the same temperature; under tropical conditions, there is a direct relationship between relative humidity and rainfall. According to Cleves et al. (2009), relative humidity has marked impact on the following variables:

- Distribution of pathogens.

- Selection of the support system

- Planting orientation

- Fruit quality (size, weight, flavor)

- Productivity

- Activity of pollinating agents

- Plant physiology

- Adequate relative environment humidity ensures fruit quality, which is expressed in greater weight and volume, with juice of excellent flavor.

In natural or assisted pollination processes, high relative humidity is required (greater than $70 \%$ ), which subsequently affects fruit setting and filling phases, and lower humidity affects pollen viability, and it has been observed that in locations with low $\mathrm{RH}$, fruit size is smaller (FISCHER et al., 2009).

In regions with low relative humidity, fruit size decreases and pollen dehydrates, preventing its positioning on the anthers. On the other hand, in extreme cases, that is, with saturated atmosphere (close to $100 \%$ ), the metabolic activities of plants are affected by reducing the difference between the water vapor concentration in the plant and the atmosphere, so that the Vapor Pressure Deficit (VPD) tends to zero, decreasing the transpiratory current, 
causing stomatal closure, affecting the accumulation of photosynthesis compounds (FISCHER et al., 2018; SALISBURY; ROSS, 2000).

1.3 Rainfall: Under tropical conditions, temperature and photoperiod are relatively uniform throughout the year and the climatological variable that has the greatest impact on growth, development and production is rainfall (RAMÍREZ et al., 2021). Its bimodal distribution in the Andean region and monomodal in the Orinoqía defines fruit volume, quantity and quality, as well as the flowering and harvesting seasons (CLEVES et al., 2021).

Water is essential for the crop to significantly express its production potential (CORONADO et al., 2013). The water requirements for passion fruit cultivation have been empirically estimated between 2.2 to $4.8 \mathrm{~mm}$ / day. The best productions are obtained with water availability and application between 1.8 to $2.0 \mathrm{M}^{3} / \mathrm{plant} /$ year (CARVALHO et al., 2000). Studies have shown that the adequate water availability and opportunity is associated with crop longevity (duration), favoring growth and development, increasing productivity and quality (SOUSA et al., 2006). This variable has marked impact on the following aspects:

- Definition of the planting orientation

- Selection of the support system

- Sowing depth

- Height of furrows (balcony)

- Sowing dates

- Harvest times

- Monthly production volume

- Infrastructure

- Design of the irrigation and drainage system.

Although passion fruit cultivation is adapted to tropical conditions, like all technical cultivars planted for commercial purposes, it requires adequate water supply estimated to be between 800 and $1500 \mathrm{~mm} /$ year, and to obtain best results, adequate irrigation system is required, so that this resource can be made available at critical times, fundamentally in dry seasons, which under normal conditions, coincide with fruit flowering and filling, being directly evidenced in weight, shape, size and juice percentage in relation to total weight (GARCÍA, 2002).

Excess water associated with poor drainage causes the spread of root pathogens (Fusarium sp; Rhizoctonia solani; Phytium spp; Phytopthora cinnamomi), infections by leaf bacteria (Xanthomonas campestris pv. Passiflorae) and fungi (Alternaria Passiflorae; Colletrichum spum; Cladosporium herbarium); in flowers, it causes pollen washing, affecting reproductive processes, restricting the activity of pollinators (OROZCO et al., 1999).
1.4 Temperature: for passion fruit cultivation, temperature is located in a range between $21^{\circ} \mathrm{C}$ and $32^{\circ} \mathrm{C}$, with optimal temperatures between $24{ }^{\circ} \mathrm{C}$ and $28{ }^{\circ} \mathrm{C}$; temperatures above $35^{\circ} \mathrm{C}$ stimulate vegetative growth, limiting the flight of pollinating insects, simultaneously affecting fertilization processes by the dehydration of stigmas, limiting the fertilization of ovaries (CLEVES et al., 2009; FISCHER et al., 2009). Under tropical conditions, temperature is the climatological variable that presents minimal variations throughout the year (CLEVES et al., 2016).

The gradient, that is, the difference between daily maximum and minimum temperature, significantly influences fruit quality, especially in the transformation of starches into sugars. The effect of temperature on the crop is summarized as follows:

- Temperature defines the duration of vegetative and reproductive phases,

- Temperature has direct impact on the periods of floral differentiation, fertilization and fruit set,

- High temperatures dehydrate the pollen, which becomes unviable,

- High temperatures induce floral abortion,

- Lack of irrigation causes water stress.

1.5. Solar radiation: Under tropical conditions, there is sufficient solar intensity in combination with the length of the day, and passion fruit requires between 10 and 11 hours of light / day because below 8 hours of light / day, floral differentiation is inhibited (DIDIER, 2001). The quantity and quality of light as well as its duration (photoperiod) expressed in hours / light / day has great influence on reproductive development and growth, specifically at pollination and fertilization phases. Fruit quality is directly related to the light exposure of the leaf area of plants (AMAYA, 2009). Fruits exposed to full sun decrease in weight but have higher juice percentage, greater amounts of ascorbic acid, soluble solids and the cortex is thinner. The effect of this climatic variable is synthesized in the following points:

- It stimulates the afternoon flower opening,

- Its continuity in a period of four hours continuously increases the floral set percentage,

- The combination of high solar radiation and relative humidity favors the activity of the pollinating entomofauna,

- Periods of low rainfall and high sunlight have negative impact on fruit quality, cortex decreases in thickness, becoming brittle, facilitating the entry of pathogenic insects and fungi,

- Excess is reflected in the decrease in fruit size and weight, 
- In fruits, it affects the quality referred to the concentration of total soluble solids (TSS).

- It increase juice percentage,

- When the crop is at juvenile formation stages, excess of leaf radiation causes irreversible mechanical damage to the fruit.

- It is a variable that defines the planting orientation and the support or trellising system.

- This variable is linked to the concentration of soluble solids.

- Limited sunshine coupled with high cloudiness decreases the activity and effectiveness of pollinating agents and pollen viability and availability (ARIAS et al., 2016).

2. Support and conduction systems: Support or conduction systems are the most important item, representing up to $70 \%$ of total production costs. Their use also has significant environmental connotations due to the excessive use of timber in some cases.

Under these conditions, it is important to know attributes, advantages, disadvantages in relation to the ecophysiological offer of the selected area to develop any production process.

The selection of the support system, as well as the planting distance, is a function of multiple factors, among which target market (production destination), environmental conditions and level of soil fertility, as shown in Table 4.

Table 4. Planting distance for passion fruit cultivation (Passiflora edulis Sims $f$. Flavicarpa and $f$. Pupurea Degener) in Colombia.

\begin{tabular}{lcccc}
\hline \multicolumn{1}{c}{$\begin{array}{c}\text { Support } \\
\text { system }\end{array}$} & $\begin{array}{c}\text { Planting } \\
\text { distance } \\
(\mathbf{m})\end{array}$ & $\begin{array}{c}\text { No. of } \\
\text { rows } / \mathrm{ha}^{-1}\end{array}$ & $\begin{array}{c}\text { No. of } \\
\text { plants } / \text { row }\end{array}$ & $\begin{array}{c}\text { Plant } \\
\text { density } \\
\text { ha }^{-1}\end{array}$ \\
\hline $\begin{array}{l}\text { Simple } \\
\text { trellis }\end{array}$ & $3.0 \times 2.5$ & 40.0 & 33.33 & 1333 \\
\hline "T" system & $3.0 \times 4.0$ & 33.3 & 33.33 & 1111 \\
\hline $\begin{array}{l}\text { Double } \\
\text { cordon }\end{array}$ & $4.0 \times 4.0$ & 25.0 & 33.33 & 833 \\
\hline
\end{tabular}

Source: Own elaboration (2021), based on Rojas (2017).

2.1 Trellis system: This support and conduction system is the one that allows the highest planting density, with distance between plants of $3 \mathrm{M}$ and between rows of $3 \mathrm{M}$ (1111 plants / ha $\mathrm{h}^{-1}$ ), being able to reduce the distance between rows at $2.5 \mathrm{M}\left(1333\right.$ plants $\left./ \mathrm{ha}^{-1}\right)$, if management is carried out manually (without mechanization) and in high fertility soils (CLEVES et al., 2012).
This system originates from a template that acts as a guide and a counterforce, intersperses the use of wooden posts every $27 \mathrm{M}$; each post with diameter of $20 \mathrm{~cm}$ and length of $3 \mathrm{~m}$ are placed at depth of 80 at $100 \mathrm{~cm}$. In the 27 -meter path, 2 bamboo varieties are placed at distance of $9 \mathrm{~m}$ from each other.

In the upper part, 10-gauge wire is placed, which is secured with two staples at height of $1.80 \mathrm{~m}$, which is the most used system (even in the cultivation of other passion flowers such as gulupa (Passiflora edulisf. Edulis Sims) (OCAMPO; WYCKHUYS, 2012). This support system has great advantages, the only limitation is that in regions with high solar radiation, low relative humidity and low cloudiness, it predisposes fruits to the so-called "sun blow".

\section{Characteristics:}

- Recommended in areas with strong winds,

- Orientation must preserve the action of prevailing winds,

- Facilitates cultural tasks of pruning the suckers, pergola training system and pollination,

- Contributes to the efficiency of foliar sprays (phytosanitary control and foliar fertilization),

- For greater photosynthetic efficiency, it is recommended application with east-west orientation,

- Facilitates evaluation of fertilization and fruit setting percentages,

- It is the system with the least predisposition to the occurrence of damage to its structure,

- In the event of a fall in the structure, it is easy to solve, because rows are independent,

- It is the most suitable system in hot and humid areas,

- Presents the highest sowing density,

- Facilitates the incorporation of other crops in associated and intercropped form (melon, watermelon, squash, corn),

- Facilitates the movement and activity of pollinating agents,

- It is mainly implemented on relatively flat terrain (slope less than $15 \%$ ).

- It is capable of implementing mechanization processes with implements for the control of weeds and foliar sprays,

- Fruits are smaller in size but productivity is higher and with optimum Brix degrees (10-13).

- The objective is to satisfy regional or national markets,

- Cycle duration (sowing to renewal): 18-24 months.

2.2 "T" support system: It is a variation of the simple trellis support system, only that the width of rows is $1 \mathrm{~m}$. This system requires greater use of materials and labor, which are expressed in higher installation and maintenance costs. 


\section{Characteristics:}

- Compared to the previous support system, it has lower sowing density (plants / ha),

- Flowers that originate in the upper part cannot be manually pollinated,

- Ripe fruits get tangled in the "ceiling",

- It is useful in hillside areas (slope less than 20\%),

- Recommended for areas with high relative humidity and cloudiness,

- It requires greater investment in agrochemicals and labor for phytosanitary controls, aeration),

- It increases the photosynthetic area (greater

- It is of medium susceptibility to falls due to the action of strong winds,

- In the event of fall, damage is greater since rows are supported by three wires,

- It has greater water retention in the soil (less evaporation),

- Fruits are larger, but smaller in volume, compared to the trellis system,

- Due to the characteristics of the product, it can be offered in markets with greater demand, either national or for export as fresh fruit,

- Cycle duration (sowing to renewal): 18 months.

2.3 Total trellis or barbecue: All posts are placed in $9 \mathrm{~m} * 9 \mathrm{~m}$ squares, forming a perfect grid. A 10-gauge wire is placed on the outer perimeter, from which 16-gauge wire is inserted each meter.

\section{Characteristics:}

- Lower sowing density,

- Indicated for areas of high cloudiness and low sunlight,

- Less water loss due to evapotranspiration,

- Useful on steep slopes (30\%),

- High degree of difficulty in phytosanitary control works,

- The practice of artificial pollination is impossible,

- In the upper part, a layer where the fruit is entangled is formed,
- Predisposition to the occurrence of damage due to sunburn in fruits,

- Harvest is carried out with fruits fallen to the ground,

- In the event of falls, recovery is very expensive,

- Production destined for regional markets,

- In areas with high incidence of snakes, it is common to affect workers,

- Cycle duration (sowing to renewal): 14 months.

\section{Production}

3.1 Pollinating agents: The first flowering occurs 4 months after sowing (DAS), floral opening begins at 11:00 am and ends at 08:00 pm, and this period of only 9 hours must present pollination otherwise the flower falls. Passion fruit is a diploid species $(2 \mathrm{n}=18)$, has hermaphrodite flowers with high degree of self-incompatibility that can reach $100 \%$, a situation that originates from the presence of sporophytic genes that act in association with gametophytic genes, and for being an allogamous flower, it requires cross pollination (SUASSUNA et al., 2000).

The transmission of pollen by the wind (anemophilic) only reaches $1 \%$; in this sense, pollination by insects (entomophilous) becomes relevant, and the main species is the bumblebee of the genus Xylocopa sp (Hymenoptera: Anthophoridae) (GARCÍA, 2010), and its activity increases the percentage of fertilized flowers by up to 70 to $80 \%$ (ARIAS et al., 2014). Temperatures in a range from 20 to $25^{\circ} \mathrm{C}$ promote the activity of pollinating agents and therefore the number of pollinated flowers (FISCHER et al., 2018). Another pollinating species is the honey bee (Apis melifera: Hymenoptera, Apidae) and the black wasp (Polystes sp: Hymenoptera, Vespidae) and occasionally birds such as the hummingbird (SALINAS, 2010).

Fertilization takes place four hours after pollination, the fertilized fruit takes on a bright green color and reaches its maximum growth after 18 days, achieving harvest maturity between 50 to 60 days. Manual or assisted pollination is necessary when the pollinating entomofauna is very low due to management techniques based on the high use of chemical products (TORRES, 2018). The efficiency of the different pollinators is shown below (Table 5).

Table 5. Efficiency (\%) of pollinating agents of the passion fruit crop (Passiflora edulis Sims f. Flavicarpa and $f$. Pupurea Degener).

\begin{tabular}{lc}
\hline \multicolumn{1}{c}{ Pollinating agent } & Efficiency (\%) \\
\hline Carpenter beetle (Xilocopa frontalis; Xilocopa grisescens; Xilocopa suspecta), Xilocopa fimbriata; & $45-83$ \\
Xilocopa aenipennis. & $10-18$ \\
Honey bee (Aphis melifera); Euglossine bee (Eulaema cingulata) & $10-18$ \\
Avispa escolida negra (Polystes sp) & 1 \\
Wind (anemófila) & $80-90$ \\
Operator-assisted pollination (manual) & $5-6$ \\
Self-pollination &
\end{tabular}

Source: Own elaboration (2021), based on Cleves et al. (2012); Flórez (2013). 
3.3.2 Productivity: The results obtained in accumulated historical production records of 30 years (1987-2017) are shown below (Table 6).

Table 6. Productivity / trellising system / quality for passion fruit cultivation (Passiflora edulis Sims f. Flavicarpa and f. Pupurea Degener) in Colombia.

\begin{tabular}{lccc}
\hline $\begin{array}{c}\text { Support } \\
\text { system }\end{array}$ & $\begin{array}{c}\text { Productivity } \\
\left(\mathrm{t}^{*} \mathrm{há}^{-1}\right)\end{array}$ & Qualities & Percentage \% \\
\hline Simple & & $1^{\mathbf{a}}$ & 75.33 \\
trellis & 30 & $2^{\mathbf{a}}$ & 24.67 \\
& & Extra & 22.42 \\
"T" system & 23 & $1^{\mathbf{a}}$ & 58.41 \\
& & $2^{\mathbf{a}}$ & 19.15 \\
Double & 20 & $1^{\mathbf{a}}$ & 51.78 \\
cordon & & $2^{\mathbf{a}}$ & 48.22 \\
\hline
\end{tabular}

Source: Own elaboration (2021), based on accumulated historical averages of 30 years (1987-2017).
As can be seen, the support system that brings together the greatest advantages that are expressed in higher productivity and quality is the simple trellis system, the " $T$ " system, intermediate behavior while total trellis presents severe limitations. The distribution of annual production expressed as percentage is shown below (Table 7).

There are two marked harvest seasons, the first occurs in the first semester from June to August, where $36 \%$ of the total production volume is obtained; the second harvest occurs in the months of November, December and January, with $35 \%$ of the production and two intermediate harvests from February to May (15\%) and in the months of September and October (14\%) (Figure 1).

Table 7. Distribution of the monthly passion fruit production (\%) (Passiflora edulis Sims f. Flavicarpa and f. Pupurea Degener) in central Colombia.

\begin{tabular}{ccccccccccccc}
\hline Month & Jan & Feb & Mar & April & May & Jun & Jul & Aug & Sep & Oct & Nov & Dec \\
\hline$\%$ & $\mathbf{7}$ & 3 & 2 & 4 & 6 & $\mathbf{9}$ & $\mathbf{1 5}$ & $\mathbf{1 2}$ & 6 & 8 & $\mathbf{1 3}$ & $\mathbf{1 5}$ \\
\hline
\end{tabular}

Source: Own elaboration (2021), based on accumulated historical averages of 30 years (1987-2017).

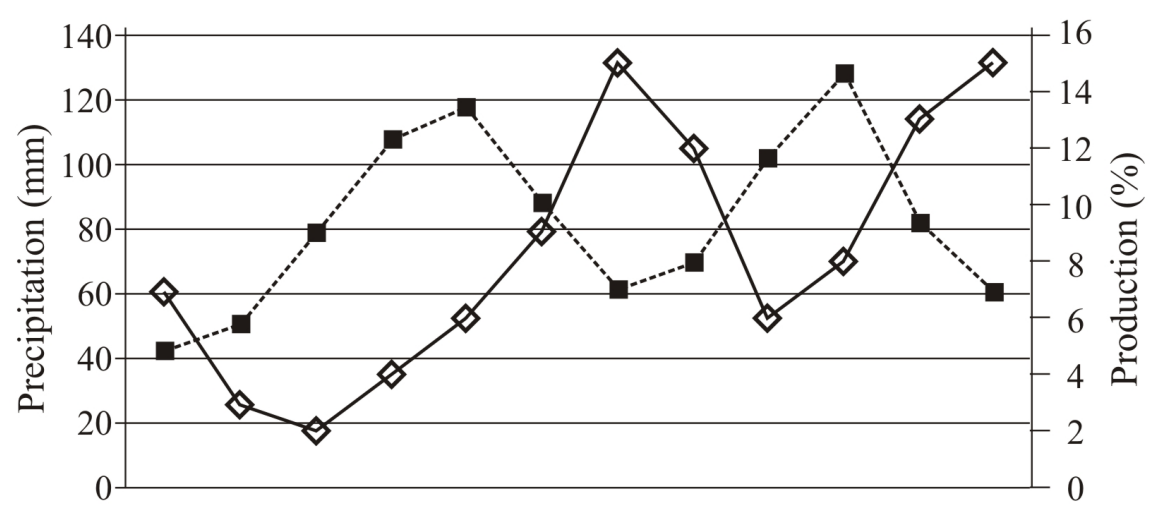

Jan Feb Mar Apr May Jun Jul Aug Sep Oct Nov Dic

Month

-.-- Precipitation $\diamond$ Production

Figure 1. Relationship between multiannual monthly average rainfall $(\mathrm{mm})$ and monthly production distribution (\%) for passion fruit cultivation (Passiflora edulis Sims f. Flavicarpa and f. Pupurea Degener) in the central region of Colombia. Source: Own elaboration, (2021), based on historical averages accumulated 30 years (1987-2017) for variable rainfall vs annual production distribution expressed as percentage (\%). 
It can be seen that the months with the highest rainfall March, April and May (first semester) and September, October and November (second semester) induce flowering, so that harvests coincide with the months with the lowest rainfall, June to August and November to January, and variable rainfall has inverse relationship with the production component. In the first year, $60 \%$ of the production volume is obtained and in the second, $40 \%$.

In the central region of Colombia, where bimodal rainfall distribution occurs and if irrigation is available, historical production records indicate that the most suitable times to start transplanting to the field are the months of January-February and June-July (months of low rainfall), showing $10 \%$ increase in productivity. When analyzing the distribution of variables monthly average temperature $(\mathrm{T})$, relative humidity $(\mathrm{RH})$, slight oscillations are observed throughout the year. In relation to variable sunshine (SS), as it is logical, increases are observed in the months of low rainfall (Figure 2).
Experimentally, it has been possible to demonstrate that the passion fruit plant has estimated production potential of $90 \mathrm{Kg}$ / plant / cycle, due to the genetic erosion of the propagation material and management techniques. Production is currently estimated between 24.6 and 31.7 $\mathrm{kg}$ / plant / cycle (350 to 450 fruits / plant, with average weight of $70.5 \mathrm{gr} /$ fruit).

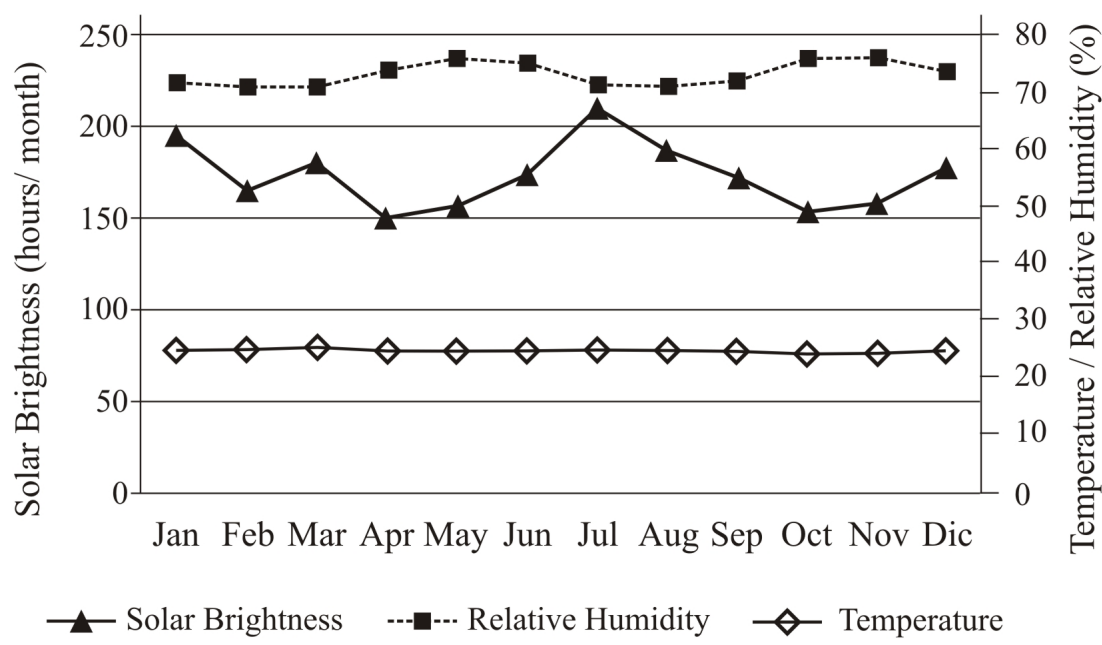

Figure 2. Behavior of variables sunshine, average temperature and relative humidity in the central region of Colombia. Source: Own elaboration, (2020), based on accumulated historical averages of 30 years (1987-2017).

\section{Conclusions}

- The greatest advantages in terms of productivity, quality, phytosanitary management and longevity are obtained with the simple trellis support system (1 wire).

- The climatological variable that has the greatest impact on physiological processes of passion fruit is rainfall.

- Under the conditions in which the work was carried out, climatological variables Temperature and Relative Humidity showed very slight inter and intra annual oscillations.

- The highest percentage of fruits produced is intended for fresh consumption, but it is advisable to implement transformation processes to generate added value.
- Fruit quality and production are linked to pollination and fruit setting processes, where the population of entomopathogens together with cultural practices (crop management and artificial pollination) have the best results to maximize productivity.

- Increased productivity requires the introduction, evaluation and release of new germplasm accompanied by rural extension and / or technology transfer programs.

- Commercial productions only reach $30 \%$ of the genetic potential, leaving a wide margin to carry out technological and cultural innovations. 


\section{References}

ARIAS, J.; OCAMPO, J.; URREA, R. La polinización natural en el maracuyá (Passiflora edulis $f$. Flavicarpa Degener) como un servicio reproductivo y ecosistémico. Agronomía Mesoamericana, San Jose, v.25, n.1, p.7383, 2014.

ARIAS, J.; OCAMPO, J.; URREA, R. Sistemas de polinización en granadilla (Passiflora liguraris Juss), como base para estudios genéticos y de conservación. Acta Agronómica, Busdapest, v.65, n.2, p.197-203, 2016.

AULAR, J.; RUGGIERO, C.; DURIGAN, J. Relación entre el color de la cáscara y las características del fruto y jugo de la parchita maracuyá. Bioagro, Barquisimeto, v.14, n.1, p. 47-51, 2002.

AVILÁN, L.; LEAL, F; BAUTISTA, D. Manual de fruticultura. Principios y manejo de producción. 2.ed. Caracas: Editorial América CA, 19912. v.2, p.993-1019.

AMAYA, R. El cultivo del maracuyá, Passiflora edulis form. Flavicarpa. Trujillo: Gerencia Regional Agraria La Libertad, 2009.

ARISTIGUIETA, L. Frutos comestibles de Venezuela. Boletin de la Sociedad Venezolana de Ciencias Naturales, Caracas, v.13, n. 76, p.57-104, 1950.

BLANCKE, R. Tropical fruits and other edible plantas of the word. Ithaca: Cornell University Press, 2016. 337 p.

CAMPOS, D.; CHIRINOS, R.; GÁlVEZ, L.; PEDRESCHI, R. Bioactive potential of Andean fruits, seeds, and tubers. In: TOLDRA, F. (ed.). Advances in food and nutrition research. Cambridge: Elsevier, 2018. v.84, p.287-343.

CARVALHO, A.; MARTINS, J.; MONNERAT, D.; BERNARDO, S. Adubação nitrogenada e irrigação no maracujazeiro amarelo. Produtividade e qualidade dos frutos. Pesquisa Agropecuária Brasileira, Brasília, DF, v.35, n.6, p.1101-1108, 2000.
CLEVES-LEGUIZAMO, J.A.; JARMA, A; FONSECA, J. Manejo integrado del cultivo de maracuya (Passiflora edulis $f$. Flavicarpa). In: MIRANDA, D.; FISCHER, G.; CASIERRA, F. (ed.). Cultivo, poscosecha y comercilizacion de las pasifloras en colombia: maracuya, ganadilla, gulupa y curuba. Bogotá: Sociedad Colombiana de Ciencias Hortícolas, 2009. p.97-119.

CLEVES-LEGUIZAMO, J.A.; JARMA, A.; PUENTES, G. Maracuyá. In: FISCHER, G. (ed.). Manual para el cultivo de frutales en el trópico. Bogotá: Produmedios, 2012. p.682-700.

CLEVES-LEGUIZAMO, J.A.; TORO, J.; MARTINEZ, L. Los balances hídricos agrícolas en modelos de simulación agroclimáticos. Una revisión analítica. Revista Colombiana De Ciencias Hortícolas, Tunja, v.10, n.1, p.149-163, 2016.

CLEVES-LEGUIZAMO, J.A.; RAMÍREZ, L.; DÍAZ, E. Proposal of an empirical model to estimate the productivity of Valencia orange (Citrus sinensis L. Osbeck) in the colombian low tropics. Revista Colombiana de Ciencias Hortícolas, Tunja, v.15, n.3, p.1-21, 2021.

CORONADO, D.; TAFUR, H.; RIOS, L. Rendimiento y calidad de la fruta del maracuyá amarillo (Passiflora edulisf. Flavicarpa o. deg.) en respuesta a la combinación del riego y la fertilización. Revista Ingeniería de los Recursos Naturales y del Ambiente, Cali, v.12, p.109$117,2013$.

DAMATTO, E.; LEONEL, S.; PEDROSO, J. Adubação orgânica na produção e qualidade de frutos demaracujádoce. Revista Brasileira de Fruticultura, Jaboticabal, v.27, n.1, p.188-190, 2005.

DELGADO, C.; CASTAÑO, J.; VILLEGAS, B. Caracterización del agente causante de la Roña del Maracuyá (Passiflora edulis f. flavicarpa Degener) en Colombia. Revista de la Academia Colombiana de Ciencias Exactas, Físias y Naturales, Bogotá, v.37, n.143, p.215-227, 2013.

DIDIER, C. Growing passion fruit. Tropical Fruits Newsletter, Paris, p.38-39, 2001.

ESCOBAR, L. La sistemática y evolución de las Passifloraceas. In: SIMPOSIO INTERNACIONAL DE PASSIFLORAS, 1., 1991, Palmira. Memórias [...]. Universidad Nacional de Colombia, 1991. p.51-54. 
FALEIRO, F.; VILELA, N.; GÓES, T.; NUNES DE JESÚS, O; MIRANDA, D.; CAMPOS, W. Advances in Passion fruit (Passiflora spp.) propagation. Revista Brasileira de Fruticultura, Jaboticabal, v. 41, n. 2, 2019.

FALEIRO, F.; JUNQUEIRA, N.; NUNES DE JESUS, O.; CENCI, S.; MACHADO, C.; ROSA, R.; COSTA, A.; JUNQUEIRA, K.; JUNGHANS, T. Maracuyá: Passiflora edulis Sims. In: RODRÍGUEZ, A; FALEIRO, F; PARRA, M.; COSTA, A. (eds.). Pasifloras: especies cultivadas en el mundo. Brasilia (DF): ProImpress, 2020. p.15-29.

FISCHER, G.; CASIERRA, F.; PIEDRAHITA, W. Ecofisiología de las especies pasifloráceas cultivadas en Colombia. In: MIRANDA, D; FISCHER; G.; CASIERRA, F. (ed.). Cultivo, poscosecha y comercialización de las pasifloráceas en Colombia: maracuyá, granadilla, gulupa y curuba. Bogotá: Sociedad Colombiana de Ciencias Hortícolas, 2009, p.45-67.

FISCHER, G. Ecophysiological aspects of fruit growing in tropical highlands. Acta Horticulturae, The Hague, v.531, p.91-98, 2000.

FISCHER, G.; PARRA, A.; MIRANDA, D. Postharvest quality response of fruits to preharvest climatic factors. Agronomia Colombiana, Bogotá, Supl. 1, p.S1415-S1418, 2016.

FISCHER, G.; MELGAREJO, L.; CUTLER J. Pre-harvest factors that influence the quality of passion fruit: A review. Agronomía Colombiana, Bogotá,v.36, n.3, p.217-226, 2018 .

FLÓREZ, M. Evaluacion del efecto de la polinizacion en la fecundacion de flores y cuaje de frutos en el cultivo de maracuyá (Passiflora edulis) en la vereda espinal, Municipio los Santos en el departamento de Santander. 2013. (Monografia) - Escuela de de Ciencias Agricolas, Pecuarias y del Medio Ambiente, Agronomia. Universidad Abierta y a Distancia UNAD, Bucaramanga, 2013.

FNC - Federacion Nacional de Cafeteros de Colombia. El cultivo del maracuya. Bogotá, 1987. 56 p. (Cartilla divulgativa).

GARCIA, M. Guia tecnica del cultivo de maracuyá amarillo. El Salvador: Centro Nacional de Tecnologia Agropecuaria y Forestal, 2002.
GARCÍA, M. Guía técnica del cultivo de Maracuyá. Republica El Salvador: Centro Nacional de Tecnología Agropecuaria, Programa Frutales, 2010. 33p. Disponível em: http://centa.gob.sv/docs/guias/frutales/GUIA $\% 20$ MARACUYA\%202011.pdf

IDEAM - Instituto de Hidrología, Meteorología y Estudios Ambientales. Atlas climatológico de Colombia. Bogotá, 2018. 220p.

LIGARRETO, G. Recursos genéticos de especies frutícolas en Colombia. In: FISCHER, G. (ed.). Manual para el cultivo de frutales en trópico. Bogotá: Produmedios, 2012. p.35-53.

MARTÍNEZ, L.; GARCÍA, S.; SANABRIA, R. Zonificacion de las especies pasifloras comerciles en Colombia. In: MIRANDA, D; FISCHER; G.; CASIERRA, F. (ed.). Cultivo, poscosecha y comercialización de las pasifloras en Colombia: Maracuya, granadilla, gulupa y curuba. Bogotá: Sociedad Colombiana de Ciencias Hortícolas, 2009. p.18-44.

Ministerio DE AGRICUlturA. Cadena de Pasifloras. Bogotá, 2019. Disponível em: https://sioc. minagricultura.gov.co/Pasifloras/Documentos/2019-0620Cifras $\% 20$ Sectoriales.pdf

NAKASONE, H.; PAUL, R. Tropical fruits. Wallingford: CAB International, 1998. p.270-291.

NUNES DE JESÚS, O.; FALEIRO, F. Maracujá classificação botânica e biodiversidade. Brasilia (DF): Embrapa, 2017. 341 p. Disponível em: http://www.alice.cnptia.embrapa.br/alice/handle/ doc $/ 1063217 \% 20(5$

OCAMPO, J.; COPPENS-D'EECKENBRUGGE, G.; RESTREPO, M.; JARVIS, A.; SALAZAR, M.; CAETANO, C. Diversity of Colombian Passifloraceae: biogeography and an updated list for conservation. Biota Colombiana, Bogotá, v.8, p.1-45, 2007.

OCAMPO, J.; WYCKHUYS, K. Tecnología para el cultivo de la gulupa en Colombia (Passiflora edulis f. edulis Sims). 2012. (Monografia) - Universidad Jorge Tadeo Lozano, Centro Biosistemas -CIAT-Ministerio de Agricultura y Desarrollo Rural, Colombia, Bogotá, 2012. 
OCAMPO, J.; COPPENS, G.; JARVIS, A. Distribution of the genus Passiflora L. Diversity in Colombia and its potential as an indicator for biodiversity management in thr coffee growing zone. Diversity, Illinois, v.2, n.11, p.1158-1180, 2017.

OCAMPO, J.; ACOSTA, N.; HERNÁNDEZ, J. Variability and genetic structure of yellow passion fruit (Passiflora edulis $f$. flavicarpa Degener) in Colombia using microsatellite DNA markers. Agronomía Colombiana, Bogotá, v.35, n.2, p.135-149, 2017a.

OCAMPO, J.; RODRÍGUEZ, A.; PARRA, M. Gulupa: Passiflora edulis f. edulis Sims. In: RODRÍGUEZ, A.; FALEIRO, F.; PARRA, G.; COSTA, A. (ed.). Pasifloras: especies cultivadas en el mundo. Brasilia (DF): ProImpress, 2020. p.139-157.

OROZCO, G.; BAUTISTA, L.; CASTILLO, A. Manejo poscosecha y comercialización del maracuyá. Bogotá: Convenio SENA-Reino Unido, 1999.

PRIMOT, S; RIOUX,, v.; D’EECKENBRUGGE, G.; GARCIN; F.; OCAMPO J. Variación morfológica de tres especies de curubas (Passiflora tripartita var. mollissima, Passiflora tarminiana y Passiflora mixta) y sus híbridos en el Valle del Cauca. Revista Brasileira de Fruticultura, Jaboticabal, v.27, n.3, p.467-471, 2005.

PROIMPRESS-CEPASS. Pasifloras: especies cultivadas en el mundo. Brasilia (DF): 2020, 249p.

RAMÍREZ,L.; GONZÁLEZ, G.;CLEVES-LEGUÍZAMO, J.A. Mathematical modeling of climatological data to estimate passion fruit crop yield (Passiflora edulis Sims L. $f$ Flavicarpa y $f$ Purpurea). . Revista Brasileira de Fruticultura, Jaboticabal, v.43, n.3: e-182, 2021.

REINA, C.; DUSSAN, S.; SÁNCHEZ, R. Manejo poscosecha de la calidad de maracuyá (Passiflora edulis Sims) que se comercializa en la ciudad de Neiva. 1997. (Monografia) - Universidad Surcolombiana, Facultad de Ingenieria, Programa de Ingenieria Agricola, Huila, 1997. $122 p$.

RODRÍGUEZ, N.; AMBACHEW, D.; MELGAREJO, L.; BLAIR, M. Morphological and agronomic variability among cultivars, landraces, and genebank accessions of purple passion fruit, Passiflora edulis $f$. edulis. HortScience, Amsterdam, v.55, n.6, p.768-777, 2020.
ROJAS, A. Determinación de la estructura de costos de tres sistemas de soporte para el cultivo de maracuyá (Passiflora edulis f. Flavicarpa) en el municipio de Granada-Meta. 2017. (Monografia) - Universidad Pedagógica y Tecnológica de Colombia, Tunja, 2017. $121 \mathrm{p}$.

SALISBURY, F.; ROSS, C. Fisiología de las plantas. Madrid: International Thomson, 2009. 987p.

SALINAS, A. Guía técnica para el cultivo de maracuyá, polinización en maracuyá. Valle del Cauca: Instituto de Educación Técnica Profesional de Roldanillo Valle, 2010. p.11-17.

SILVA, L.; GAVA, J.; MAGALHAES, C.; HORST, C.; MENEZES, M.; BORGES, L. Evidence of maternal effect on germination and vigor of sour passion fruit. Revista Brasileira de Fruticultura, Jaboticabal, v.42, n. 4, 2020.

SOUSA, v.; FOLEGATTI, M.; FRIZZONE, J.; CORREAA, R.; VIANA, T. Umidade do solo na zona radicular do maracujazeiro cultivado sob irrigação localizada. Engenharia Agrícola, Jaboticabal, v.26, n.2, p.365-373, 2006.

SUASSUNA, T.; BRUCKNER, C.; CARVALHO, C.; BORÉM, A. Self-incompatibility in passionfruit: evidence of gametophytic - sporophytic control. Theoretical and Applied Genetics, Berlin, v.106, p.298-302, 2000

TORRES, P. Estrategias de polinización en pasifloras, especies maracuyá amarillo (Passiflora edulis $f$ flavicarpa), granadilla (Passiflora ligularis Juss) y gulupa (Passiflora edulis Sims edulis). 2018. (Monografia) - Universidad de Ciencias Aplicadas y Ambientales (UDCA), Facultad de Ingeniería, Programa de Ingeniería Agronómica, Bogotá, 2018. 71p. Disponível em: https://repository.udca.edu.co/bitstream/ handle/11158/1034/MONOGRAFIA\%20PAULA \%20 TORRES.pdf;jsessionid=C4D24DB34C986FFAE1968 $\mathrm{A} 5 \mathrm{~B} 2 \mathrm{C} 4 \mathrm{DC} 11 \mathrm{E}$ ?sequence $=1$

TIGRERO, F.; LOVATO, S.; QUIMI, F. Estudio de factibilidad de procesadora de derivados de maracuyá. Una alternativa de desarrollo en Santa Elena, Ecuador. Ciencia Unemi, Milagro, v.9, n.17, p.21-35, 2016. 